J. Product. \& Dev12 (2): 673- 688(2007)

\title{
PRODUCTIVE AND REPRODUCTIVE PERFORMANCE OF BAUSCAT DOE RABBITS AS AFFECTED BY INJECTION OF SOME ANTIMICROBIAL.
}

\author{
S. A. Gad Alla ${ }^{1}$;El-Bolkiny ${ }^{2}$, Y.E. ; Attia ${ }^{2}$, W.Y. and Hanan M. Rabie ${ }^{1}$ \\ ${ }^{1}$ Animal Production Research Institute, Agricultural Research Center, Giza, Egypt. \\ ${ }^{2}$ Department of Zoology, Faculity of Science, Tanta University, Tanta, Egypt.
}

\section{ABSTRACT}

The present study was included two trails. The first trail was started from sexual maturity at 6 months of age up to fulfillment two parities in order to evaluate the effects of treatment with either oxytetracycline or enrofloxacin on some physiological parameters, as well as, the reproductive performance of female Bouscat rabbits, In this respect, 36 does were randomly divided into three groups. The first group was used as a control group and was subcutaneously injected with saline solution $(1 \mathrm{ml}$ of $0.9 \% \mathrm{NaCl})$. The second and three groups were subcutaneously injected with $50 \mathrm{mg}$ oxytetracycline and $2.5 \mathrm{mg}$ enrofloxacin/ $\mathrm{kg}$ body weight, respectively. The $2^{\text {nd }}$ trail, lasted 8 weeks (from weaning at 5 weeks up to 13 weeks of age) in order to evaluate the effects of injection of some antimicrobials (tetracycline and enrofloxacin) on productive performance of growing Bouscat rabbits . In this respect, 60 weaning Bouscat rabbits (30 males and 30 females, 5 weeks old), as similarly in the $1^{\text {st }}$ part.

Results showed that the live body weight was increased with oxytetracycline and decreased with enrofloxacin as compared to the control. Treatment with either oxytetracycline or enrofloxacin increased the total number of RBCs after mating and decreased it during pregnancy, lactation period and at sacrifice. The WBCs of rabbits treated with oxytetracycline and enrofloxacin were significantly increased than the control group. The platelets count of rabbits treated with oxytetracycline was decreased after mating and during pregnancy and increased during lactation and at sacrifice. In oxytetracycline-treated does, there was a slight increase in hemoglobin concentration.

The serum AST was significantly decreased in female rabbits treated with oxytetracycline one-week after the $1^{\text {st }}$ injection, ALT was also insignificantly decreased by treatment with oxytetracycline and enrofloxacin as compared with the control group. After the $1^{\text {st }}$ injection; oxytetracycline insignificantly decreased the creatinine and significantly decreased urea concentration, while enrofloxacin increased the serum levels of both creatinine and urea. At sacrifice, the progesterone level was significantly increased by treatment with oxytetracycline and enrofloxacin. Estradiol level significantly increased in both oxytetracycline and enrofloxacin-treated does after mating, during pregnancy and at sacrifice. 
Conception rate was significantly increased in doe rabbits treated with either oxytetracycline or enrofloxacin as compared to that of the control. The litter size at birth was slightly increased after treatment with either oxytetracycline or enrofloxacin, and was increased significantly at 21 and 28 days with both treatments. The litter weight at birth of treated rabbits with oxytetracycline was significantly improved followed by enrofloxacin as compared with control group. Oxytetracycline and enrofloxacin treatments significantly increased the daily milk yield at $1^{\text {st }}, 2^{\text {nd }}$ and $3^{\text {rd }}$ week of lactation period of doe rabbits as compared to that of the control group. Both oxytetracycline and enrofloxacin injections significantly increased the viability percentage during the period from birth to 21 and 28 days. Both oxytetracycline and enrofloxacin treatments significantly increased the daily weight gain from 5-9, 9-13 and 5-13 weeks of age intervals of growing rabbits.

The feed intake of growing rabbits was insignificantly increased during 5-9 and 5-13 weeks of age and insignificantly decreased during 9-13 weeks of age in treated groups. The daily feed conversion was insignificantly decreased during the period from 5-9 weeks of age of growing rabbits after either oxytetracycline or enrofloxacin treatment, however, it was significantly increased during the period from 9-13 and 5-13 weeks of age.

Key words: Tetracycline, enrofloxacin, productive and reproductive performance, blood components, rabbits.

\section{INTRODUCTION}

The domestic rabbit is considered a good laboratory animal for production because of its early sexual maturity, high prolificacy, short gestation and generation periods, sizable number of progeny kindled per doe, rapid growth and good meat quality (Cheeke et al., 1982; Lebas, 1983).

Antibiotics are added to feeds to prevent or to control diseases, to stimulate growth and to improve feed efficiency (Miles et al., 1984; Chapman and Johnson, 2002). Antibiotics have also been used widely as growth promoters particularly of anti-microbial properties (El-Sherbiny et al., 1990; Dorgham et al., 1994 and Radwan et al., 1996).

Tetracycline had protective effects against chronic aflatoxicosis enhanced by cysteine and methionine in rabbits (Clark et al., 1982). Recently, due to high levels of resistance of intestinal microorganisms, it is mainly used to control respiratory infections (Burgmann, 2000, Prescott, 2000 and Villa et al., 2001).

Enrofloxacin are used for both human and veterinary purposes in treatment of a variety of bacterial infections (Brown, 1996; Verma et al., 1999). Enrofloxacin inhibits bacterial DNA-gyrase and is administrated to cattle, pigs, chicken, turkeys, sheep, rabbits, and dogs to control bacterial infections (Navalon et al. (2002). Enrofloxacin is considered an important alternative for H. pylori eradication, (Van den Bulck et al., 2005).

The importance of the withdrawal time of antibiotics as safe way for avoiding the residues in human feeds of animal and poultry origin was stressed by different 
authors (Anadon et al., 1990 and Mignot et al., 1993). Oxytetracycline and enrofloxacin are commonly used in the treatment of infectious disease.

Therefore, this investigation was performed to study the effect of a subtherapeutic dose of either oxytetracycline $(50 \mathrm{mg} / \mathrm{kg}$ body weight) or enrofloxacin (25 mg/kg body weight) on some physiological and reproductive parameters of female Bouscat rabbits, as well as, the growth performance of growing rabbits.

\section{MATERIALS AND METHODS}

The present study was carried out at El-Gemeza Experimental Station, Animal Production, Research Institute, Ministry of Agriculture, Egypt.

The present study included two trails. The first one started from sexual maturity at 6 months of age up to fulfillment two parities in order to evaluate the effects of treatment with either oxytetracycline or enrofloxacin on some physiological responses and the reproductive performance of female Bouscat rabbits. For this purpose, 36 does aged 6 months and weighed $3067.22 \pm 41.92 \mathrm{~g}$ were randomly divided into three equal groups $(\mathrm{n}=12)$. The rabbits were housed individually in wire cages $(60 \times 55 \times 40 \mathrm{~cm})$ provided with galvanized feeders and nipple drinkers. Fresh drinking water were available all time. The animals were kept under the same environmental and managerial conditions. The basal ration was formulated in one of feed mills to meet the nutrient requirements of rabbits according to NRC (1977). The ration was offered to rabbits ad libitum. The ingredients and chemical composition of the pelleted ration are shown in Table (1). The first group was used as a control group and was subcutaneously injected with saline solution $(1 \mathrm{ml}$ of $0.9 \% \mathrm{NaCl})$. The second group was subcutaneously injected with oxytetracycline $(50 \mathrm{mg} / \mathrm{kg}$ body weight) and the third group was subcutaneously injected with enrofloxacin $(25 \mathrm{mg} / \mathrm{kg}$ body weight), every other week for 8 weeks. Blood samples were collecting after mating, during pregnancy $\left(1^{\text {st }}, 2^{\text {nd }}, 3^{\text {rd }}\right.$ and $4^{\text {th }}$ weeks $)$, during lactation $\left(1^{\text {st }}, 2^{\text {nd }}, 3^{\text {rd }}\right.$ and $4^{\text {th }}$ weeks) and at sacrifice. The physiological parameters studied were: blood cell count, hemoglobin concentration, packed cell volume, total protein and protein fractions, serum enzyme activities of liver and kidney as well as hormonal assessment. The reproductive performance of female Bouscat rabbits includes doe traits (number of mating, conception rate, gestation length, litter size, and litter weight) and milk yield, as well as, offspring traits (bunny weight, bunny weight gain and pre-weaning viability percentages). The milk yield at $1^{\text {st }}, 2^{\text {nd }}, 3^{\text {rd }}$ and $4^{\text {th }}$ weeks of lactation, was determined by the difference between body weight for either the doe or the pups before and after suckling.

Blood samples from five doe in each experimental group were collected weekly throughout 9 weeks. At each collection $5 \mathrm{ml}$ of blood were drained into two tubes. The $1^{\text {st }}$ tube was without heparin and the $2^{\text {nd }}$ was heparinized tube. A part of blood samples with heparin immediately was used for detecting the blood picture and the remaining part was centrifugated at 3000 r.p.m. for 15 minutes. Blood perform was carefully separated. The non heparinized blood samples were left to cold. Thereafter, were centrifugated of 3000 r.p.m. for 15 minutes and blood serum was carefully separated. Both blood plasma and blood serum were stored frozen $\left(-20^{0} \mathrm{C}\right)$ in plastic vials until used for the biochemical tests. Levels of serum total protein and albumen was determined according to Henery (1964) using commercial kits 
obtained from Diamond Diagnostics. The globulin values were obtained by substracting the values of albumin from the total protein and the values of $\mathrm{A} / \mathrm{G}$ ratio were also calculated. Urea-N and creatinine concentration were determined by using commercial kits of Diamond Diagnostics according to the method of Henery (1974). The activity of aspartate aminotransferase (AST) and alanine aminotransferase (ALT) was assayed according to the method described by Reitman and Frankel (1957). The levels of serum blood progesterone and estradiol were also determined by radioimmiunoassay technique, using coated kits purchased from Diagnostic Products Corporation Kits, Los Angles, U.S.A. according to the method described by Blight and White (1983) and Cuilleron and Forest (1990), respectively.

Table (1). Ingredients and chemical composition of the pelleted rations.

\begin{tabular}{|c|c|}
\hline Items & $\%$ \\
\hline \multicolumn{2}{|l|}{ Ingredients : } \\
\hline Barley grains (ground) & 12.50 \\
\hline Wheat bran & 25.00 \\
\hline Yellow corn (ground ) & 10.00 \\
\hline Soybean meal (44\%) & 15.00 \\
\hline Clover hay (ground) & 32.50 \\
\hline Molasses & 3.00 \\
\hline Limestone & 1.00 \\
\hline Vit. \& Min.premix & 0.50 \\
\hline Common salt & 0.35 \\
\hline DL-Methionine & $\underline{0.15}$ \\
\hline Total & $\overline{100.00}$ \\
\hline \multicolumn{2}{|l|}{ Chemical composition: } \\
\hline Dry matter & 90.07 \\
\hline Crude protein & 16.95 \\
\hline Ether extract & 2.77 \\
\hline Crude fiber & 12.01 \\
\hline Nitrogen free extract & 50.75 \\
\hline Ash & 7.59 \\
\hline
\end{tabular}


The $2^{\text {nd }}$ trial part, lasted 8 weeks (from weaning at 5 weeks up to 13 weeks of age) in order to evaluate the effects of injection of tetracycline and enrofloxacin) subcutanously on growth performance of growing Bouscat rabbits . For this purpose, 60 weaning Bouscat rabbits (30 males and 30 females, 5 weeks old, with an average live body weight of $517.25 \pm 4.77 \mathrm{~g}$ ), were randomly allotted into three groups (20 per each). The first group was used as a control group and was subcutaneously injected with saline solution $(1 \mathrm{ml}$ of $0.9 \% \mathrm{NaCl})$. The second one was subcutaneously injected with oxytetracycline $(50 \mathrm{mg} / \mathrm{kg}$ body weight) and the third group was subcutaneously injected with enrofloxacin $(25 \mathrm{mg} / \mathrm{kg}$ body weight), every other week for 8 weeks. Weigh ,feed and feed conversion were recorded weekly from weaning ( 5 weeks old) until 13 weeks of age. Viability percentages and economic efficiency were also recorded..

Data of the experiment were statistically analyzed according to Snedecor and Chochran (1982), using SPSS (1998). Conception rate was analyzed using Contingency Tables according to Everitt (1977). The differences between means were tested using Duncan's New Multiple Rang Test (Duncan,1955).

\section{RESULTS AND DISCUSSION}

\section{Effect of tetracycline and enrofloxacine on:}

\section{Body weight and relative weight of organs:}

Data in Table 2 showed that oxytetracycline increased the live body weight, while enrofloxacin decreased the live body weight of Bouscat rabbits as compared to the control group. These results are similar to the results obtained by Kamar et al. (1975) who found that the addition of oxytetracycline to the ration of rabbits improved live body weight and weight gain. This may indicated that the addition of oxytetracycline to rations might react against the major toxins in hemoglobin concentrates. The relative weight of the investigated organs was increased after treatment with oxytetracycline, the relative weight of the liver was similar in both enrofloxacin-treated rabbits and control group; however, the relative weight of kidneys, reproductive tracts and ovary was increased after treatment with enrofloxacin. These results are in agreement with those obtained by El-Sayaad (1997) and El-Tantawy et al. (2001 a) and El-Kassas (2005) .

Table 2. Effect of oxytetracycline and enrofloxacin treatment on the body weight and relative weights of liver, kidney, reproductive tract and ovary of female Bouscat rabbits at sacrifice.

\begin{tabular}{lcccc}
\hline \multirow{2}{*}{ Items } & \multicolumn{3}{c}{ Experimental groups } & \multirow{2}{*}{ Sig. } \\
\cline { 2 - 4 } & $\mathbf{A}$ (Control) & $\mathbf{B}$ & $\mathbf{C}$ & N.S. \\
\hline Live body weight (g) & $3173.3 \pm 398.7$ & $3580 \pm 221.21$ & $2820 \pm 170.0$ & \\
Relative weight of: & & & & \\
$\quad$ Liver (\%) & $2.66 \pm 0.08$ & $3.02 \pm 0.31$ & $2.66 \pm 0.21$ & N.S. \\
Kidney (\%) & $0.43 \pm 0.03$ & $0.53 \pm 0.04$ & $0.42 \pm 0.02$ & N.S. \\
$\quad$ Reproductive tract (\%) & $0.39 \pm 0.0003$ & $0.42 \pm 0.07$ & $0.29 \pm 0.02$ & N.S. \\
$\quad$ Ovary & $0.009 \pm 0.0003$ & $0.009 \pm 0.002$ & $0.007 \pm 0.001$ & N.S. \\
\hline
\end{tabular}

$\mathrm{NS}=$ Not significant. 


\section{Blood profile:}

The results in Table 3 show that treatment of female Bouscat rabbits with either oxytetracycline or enrofloxacin increased the total number of RBCs after mating and decreased it during pregnancy, during lactation and at sacrifice as compared to the control group. The WBCs of female Bouscat rabbits treated with oxytetracycline and enrofloxacin were significantly increased than the control group. Platelets count in female rabbits treated with oxytetracycline decreased after mating and during pregnancy and increased during lactation and at sacrifice. However, it increased after treatment with enrofloxacin after mating, during lactation and at sacrifice and decreased during pregnancy as compared to the control group. The effect of oxytetracycline and enrofloxacin may be due to their stimulatory effects on the immune responses. These results are in agreement with those obtained by ElKassas (2005).

The results showed a slight increase in hemoglobin concentration at all times of collection in oxytetracycline treated does. The same trend was observed in rabbits treated with enrofloxacin, except after mating and at sacrifice. The packed cell volume (PCV) was increased in female rabbits treated with oxytetracycline. The same trend was observed after treatment with enrofloxacin, except after mating and at sacrifice. Similar results were reported by El-Kassas (2005) who found that PCV was increased when male rabbits were treated with oxytetracycline compared to the control group. On the other hand, Fleischer et al. (2000) reported that chickens fed a diet supplemented with enrofloxacin showed a significant increase in hemoglobin concentration, but no significant effect on PCV.

\section{Liver function:}

Results of Table 4 show that serum AST was significantly decreased (P < $0.01)$ in female rabbits treated with oxytetracycline one-week after the $1^{\text {st }}$ injection, also ALT was insignificantly decreased by treatment with oxytetracycline and enrofloxacin as compared with the control group. On the other hand, AST was significantly increased after treatment with enrofloxacin. Other results were obtained by El-Kassas (2005) showed that all injection of tetracycline induced a significant reduction of plasma AST activity in male Bouscat rabbits. The level of serum enzyme activity decreased due to a wide range of inflammatory degenerative diseases of liver and kidneys (Hawk, 1965). However, El-Tantawy et al. (2001 a) reported that serum AST and ALT of Bouscat rabbits were not significantly affected by treatment with flavomycine.

\section{Kidney function:}

Data in Table 4 show that, one-week post the $1^{\text {st }}$ injection; oxytetracycline insignificantly decreased the serum creatinine and significantly decreased $(\mathrm{P}<0.05)$ urea concentration, while enrofloxacin increased the serum levels of both creatinine and urea. However, at sacrifice, serum creatinine concentrations were significantly increased, while urea concentrations were decreased after treatment with 
oxytetracycline and enrofloxacin, respectively. Creatinine level was insignificantly decreased after treatment with oxytetracycline. These results are in agreement with that reported by El-Banna and Ibrahim (1999) who found that growing Bouscat rabbits treated with virginiamycin significantly decreased the creatinine level.

Table 3. Effect of oxytetracycline and enrofloxacin treatment on some blood count of female Bouscat rabbits during the experimental periods.

\begin{tabular}{|c|c|c|c|c|c|}
\hline \multirow[t]{3}{*}{ Traits } & \multirow{3}{*}{ Items } & \multicolumn{3}{|c|}{ Treatments } & \multirow{3}{*}{ Sig. } \\
\hline & & Control & Oxytetracycline & Enrofloxacin & \\
\hline & & $\mathrm{X} \pm \mathrm{SE}$ & $\mathrm{X} \pm \mathrm{SE}$ & $\mathrm{X} \pm \mathrm{SE}$ & \\
\hline $\begin{array}{l}\text { Red blood } \\
\text { cells } \\
\left(\times 10^{6} / \mathrm{mm}^{3}\right)\end{array}$ & $\begin{array}{l}\text { After mating } \\
\text { During Pregnancy } \\
\text { At birth } \\
\text { During lactation } \\
\text { At sacrifice }\end{array}$ & $\begin{array}{l}3.65 \pm 0.4^{\mathrm{b}} \\
5.10 \pm 0.39^{\mathrm{a}} \\
6.28 \pm 0.46^{\mathrm{a}} \\
4.55 \pm 0.23 \\
5.32 \pm 0.26\end{array}$ & $\begin{array}{c}5.2 \pm 0.56^{\mathrm{a}} \\
4.19 \pm 0.20^{\mathrm{b}} \\
4.82 \pm 0.39^{\mathrm{b}} \\
4.76 \pm 0.44 \\
5.18 \pm 0.35\end{array}$ & $\begin{array}{l}4.95 \pm 0.37^{\mathrm{a}} \\
4.60 \pm 0.26^{\mathrm{a}} \\
3.84 \pm 0.28^{\mathrm{b}} \\
4.42 \pm 0.21 \\
4.78 \pm 0.33\end{array}$ & $\begin{array}{l}* \\
* * \\
* * \\
\mathrm{Ns} \\
\mathrm{Ns}\end{array}$ \\
\hline $\begin{array}{l}\text { White } \\
\text { blood cells } \\
\left(\mathbf{x} 10^{3} /\right. \\
\left.\mathrm{mm}^{3}\right)\end{array}$ & $\begin{array}{l}\text { After mating } \\
\text { During Pregnancy } \\
\text { At birth } \\
\text { During lactation } \\
\text { At sacrifice } \\
\end{array}$ & $\begin{array}{c}12.47 \pm 1.94 \\
12.12 \pm 0.83 \\
9.70 \pm 1.07^{\mathrm{b}} \\
12.96 \pm 1.04^{\mathrm{b}} \\
9.67 \pm 0.29^{\mathrm{b}} \\
\end{array}$ & $\begin{array}{c}13.37 \pm 1.53 \\
13.44 \pm 0.78 \\
16.63 \pm 1.57^{\mathrm{a}} \\
14.14 \pm 0.96^{\mathrm{a}} \\
18.80 \pm 0.44^{\mathrm{a}} \\
\end{array}$ & $\begin{array}{c}10.14 \pm 1.22 \\
13.83 \pm 0.89 \\
14.10 \pm 0.41^{\mathrm{a}} \\
13.29 \pm 0.69^{\mathrm{a}} \\
12.73 \pm 0.82^{\mathrm{b}} \\
\end{array}$ & $\begin{array}{l}\mathrm{NS} \\
\mathrm{NS} \\
* * \\
* \\
* * \\
\end{array}$ \\
\hline $\begin{array}{l}\text { Platelet } \\
\text { count } \\
\left(\mathbf{x} 10^{4}\right. \\
\left./ \mathrm{mm}^{3}\right)\end{array}$ & $\begin{array}{l}\text { After mating } \\
\text { During Pregnancy } \\
\text { At birth } \\
\text { During lactation } \\
\text { At sacrifice } \\
\end{array}$ & $\begin{array}{c}10.2 \pm 1.69^{\mathrm{a}} \\
14.10 \pm 1.87^{\mathrm{a}} \\
10.4 \pm 0.93 \\
10.8 \pm 1.60^{\mathrm{b}} \\
10.7 \pm 1.3 \\
\end{array}$ & $\begin{array}{c}7.7 \pm 0.42^{\mathrm{b}} \\
11.20 \pm 1.82^{\mathrm{b}} \\
11.20 \pm 1.98 \\
13.05 \pm 1.85^{\mathrm{a}} \\
11.9 \pm 1.9 \\
\end{array}$ & $\begin{array}{c}12.5 \pm 1.42^{\mathrm{a}} \\
12.90 \pm 1.96^{\mathrm{ab}} \\
13.0 \pm 1.95 \\
11.75 \pm 1.91^{\mathrm{ab}} \\
12.0 \pm 1.9 \\
\end{array}$ & $\begin{array}{c}* \\
* \\
\mathrm{NS} \\
* \\
\mathrm{NS} \\
\end{array}$ \\
\hline $\begin{array}{l}\text { Hemoglobi } \\
\text { n } \\
\text { concentrati } \\
\text { on }(\%)\end{array}$ & $\begin{array}{l}\text { After mating } \\
\text { During Pregnancy } \\
\text { At birth } \\
\text { During lactation } \\
\text { At sacrifice } \\
\end{array}$ & $\begin{array}{c}75.7 \pm 3.43^{\mathrm{ab}} \\
71.88 \pm 3.13^{\mathrm{b}} \\
67.5 \pm 3.06 \\
67.97 \pm 1.12 \\
70.28 \pm 0.47^{\mathrm{a}} \\
\end{array}$ & $\begin{array}{c}80.49 \pm 2.08^{\mathrm{a}} \\
76.33 \pm 3.06^{\mathrm{a}} \\
65.65 \pm 2.29 \\
69.32 \pm 1.62 \\
73.26 \pm 1.35^{\mathrm{a}} \\
\end{array}$ & $\begin{array}{c}71.9 \pm 1.83^{\mathrm{b}} \\
77.06 \pm 4.35^{\mathrm{a}} \\
65.9 \pm 2.12 \\
67.64 \pm 1.16 \\
61.5 \pm 2.03^{\mathrm{b}} \\
\end{array}$ & $\begin{array}{c}* \\
* \\
\mathrm{NS} \\
\mathrm{NS} \\
* *\end{array}$ \\
\hline $\begin{array}{l}\text { Packed } \\
\text { cell } \\
\text { volume }\end{array}$ & $\begin{array}{l}\text { After mating } \\
\text { During Pregnancy } \\
\text { At birth } \\
\text { During lactation } \\
\text { At sacrifice } \\
\end{array}$ & $\begin{array}{c}36.34 \pm 1.65^{\mathrm{ab}} \\
34.50 \pm 1.51^{\mathrm{b}} \\
32.4 \pm 1.47 \\
32.62 \pm 0.86 \\
33.73 \pm 0.23^{\mathrm{b}} \\
\end{array}$ & $\begin{array}{c}38.64 \pm 1.00^{\mathrm{a}} \\
36.64 \pm 1.45^{\mathrm{a}} \\
31.51 \pm 1.1 \\
33.30 \pm 0.79 \\
35.16 \pm 0.65^{\mathrm{a}} \\
\end{array}$ & $\begin{array}{c}34.51 \pm 0.88^{\mathrm{b}} \\
36.99 \pm 2.06^{\mathrm{a}} \\
31.63 \pm 1.02 \\
32.47 \pm 0.58 \\
29.52 \pm .97^{\mathrm{b}} \\
\end{array}$ & $\begin{array}{c}* \\
* \\
\mathrm{NS} \\
\mathrm{NS} \\
* *\end{array}$ \\
\hline
\end{tabular}

Means in the same row are bearing different letters, differ significantly $(\mathrm{P}<0.05)$.

$* *=\mathrm{P}<0.01, \quad *=\mathrm{P}<0.05, \quad \quad$ N.S $=$ Not significant.

\section{Hormone levels:}

The progesterone level after mating decreased insignificantly after treatment with both oxytetracycline and enrofloxacin. However, during pregnancy and lactation, the level of progesterone was decreased after treatment with enrofloxacin and was increased with oxytetracycline (Table 5). Moreover, at sacrifice, the progesterone concentration was significantly increased by treatment with oxytetracycline and enrofloxacin. El-Tantawy et al. (2001b) reported a significant $(P<0.05)$ increase in blood plasma progesterone level during pregnancy in Bouscat rabbits treated with flavomycin. Habeeb and El-Masry (1991) found that, in New Zealand White( NZW) female rabbits, the progesterone concentration was increased significantly at the first 
half of pregnancy then decreased significantly near the end of pregnancy, but maintaining level higher than those recorded in the non-pregnant rabbits.

Table 4. Effect of oxytetracycline and enrofloxacin treatment on liver and kidney function of female Bouscat rabbits one week after the $1^{\text {st }}$ injection and sacrifice.

\begin{tabular}{|c|c|c|c|c|c|}
\hline \multirow[b]{3}{*}{ Parameters } & \multirow{3}{*}{$\begin{array}{r}\text { Time of } \\
\text { sampling }\end{array}$} & \multicolumn{3}{|c|}{ Treatments } & \multirow{3}{*}{ Sig. } \\
\hline & & Control & Oxytetracycline & Enrofloxacin & \\
\hline & & $\mathbf{X} \pm \mathbf{S E}$ & $\mathrm{X} \pm \mathrm{SE}$ & $\mathrm{X} \pm \mathrm{SE}$ & \\
\hline \multirow[t]{2}{*}{$\overline{\text { AST (U/ml) }}$} & $1^{\text {st }}$ injection & $9.4 \pm 1.2^{b}$ & $8.2 \pm 0.73^{b}$ & $14.2 \pm 0.73^{\mathrm{a}}$ & $* *$ \\
\hline & At sacrifice & $5.6 \pm 0.86$ & $5.6 \pm 0.86$ & $7.0 \pm 0.001$ & NS \\
\hline \multirow{2}{*}{$\operatorname{ALT}(\mathrm{U} / \mathrm{ml})$} & $1^{\text {st }}$ injection & $6.08 \pm 1.18$ & $3.52 \pm 0.60$ & $4.16 \pm 1.20$ & $\mathrm{NS}$ \\
\hline & At sacrifice & $4.8 \pm 0.88$ & $4.16 \pm 1.51$ & $6.08 \pm 1.06$ & NS \\
\hline \multirow{2}{*}{$\begin{array}{l}\text { Creatinine } \\
\text { (mg/dl) }\end{array}$} & $1^{\text {st }}$ injection & $0.80 \pm 0.25$ & $0.66 \pm 0.001$ & $0.93 \pm 0.16$ & $\mathrm{NS}$ \\
\hline & At sacrifice & $1.06 \pm 0.16^{\mathrm{ab}}$ & $0.99 \pm 0.37^{b}$ & $1.73 \pm 0.304^{\mathrm{a}}$ & $*$ \\
\hline \multirow[t]{2}{*}{ Urea (mg/dl) } & $1^{\text {st }}$ injection & $44.94 \pm 2.49^{\mathrm{ab}}$ & $34.22 \pm 4.6^{6}$ & $52.34 \pm 5.24^{\mathrm{a}}$ & $* *$ \\
\hline & At sacrifice & $52.70 \pm 1.9$ & $46.93 \pm 2.5$ & $48.90 \pm 1.1$ & NS \\
\hline
\end{tabular}

Means in the same row are bearing different letters, differ significantly $(\mathrm{P}<0.05)$.

$* *=\mathrm{P}<0.01, \quad * *=\mathrm{P}<0.05, \quad$ N.S $=$ Not significant.

The high level of progesterone during the early pregnancy period plays a role in the preparation of the uterus for implantation of the fertilized ovum and inhibition of uterine contraction during the first few days of pregnancy (Bryand-Green et al., 1982). The high progesterone and estrogen titers shut off the luteinizing hormone release from the pituitary gland prevent induction of ovulation during pregnancy in rabbits (Sharma, 1979). The fall in progesterone titer in late pregnancy in rabbits is the first step in initiation of parturition, where prostaglandins participate in later stages of parturition by expelling fetuses through their oxytocin property (Enbergs, 1979).

Table 5. Effect of oxytetracycline and enrofloxacin treatment on serum progesterone and estradiol level of female Bouscat rabbits during the experimental period.

\begin{tabular}{|c|c|c|c|c|c|}
\hline \multirow{3}{*}{ Items } & \multicolumn{4}{|c|}{ Treatments } & \multirow{3}{*}{ Sig. } \\
\hline & & \multirow{2}{*}{$\begin{array}{l}\text { Control } \\
\mathrm{X} \pm \mathrm{SE} \\
\end{array}$} & \multirow{2}{*}{$\begin{array}{l}\text { Oxytetracyclin } \\
\text { e } \\
\qquad \mathrm{X}+\mathrm{SE}\end{array}$} & \multirow{2}{*}{$\begin{array}{c}\text { Enrofloxacin } \\
\mathrm{X} \pm \mathrm{SE}\end{array}$} & \\
\hline & & & & & \\
\hline \multirow{5}{*}{$\begin{array}{l}\text { Progesterone } \\
(\mathrm{ng} / \mathrm{ml})\end{array}$} & After mating & $6.73 \pm 2.81$ & $5.55 \pm 2.38$ & $6.43 \pm 1.89$ & $\mathrm{NS}$ \\
\hline & During pregnancy & $6.91 \pm 0.73^{b}$ & $8.40 \pm 1.13^{\mathrm{a}}$ & $6.44 \pm 1.62^{b}$ & $*$ \\
\hline & At birth & $0.07 \pm 0.02^{\mathbf{b}}$ & $3.43 \pm 0.71^{\mathrm{a}}$ & $0.04 \pm 0.02^{b}$ & $*$ \\
\hline & During lactation & $0.68 \pm 0.22^{\mathrm{b}}$ & $2.16 \pm 0.64^{\mathrm{a}}$ & $0.1 \pm 0.04^{\mathrm{b}}$ & $* *$ \\
\hline & At sacrifice & $0.02 \pm 0.01^{\mathrm{b}}$ & $0.05 \pm 0.01^{\mathrm{ab}}$ & $0.11 \pm 0.4^{\mathrm{a}}$ & $* *$ \\
\hline \multirow{5}{*}{ Estradiol (pg/ml) } & After mating & $23.11 \pm 2.93^{b}$ & $27.87 \pm 0.75^{\mathrm{a}}$ & $28.92 \pm 6.17^{\mathrm{a}}$ & $* *$ \\
\hline & During pregnancy & $20.01 \pm 2.95^{\mathrm{c}}$ & $43.61 \pm 1.83^{\mathrm{a}}$ & $32.29 \pm 4.88^{\mathrm{b}}$ & $* *$ \\
\hline & At birth & $24.46 \pm 1.90$ & $30.64 \pm 3.70$ & $29.26 \pm 5.08$ & NS \\
\hline & During lactation & $33.68 \pm 1.84^{\mathrm{b}}$ & $30.99 \pm 3.82^{\mathrm{b}}$ & $53.15 \pm 3.85^{\mathrm{a}}$ & $*$ \\
\hline & At sacrifice & $5.23 \pm 0.64^{\mathrm{c}}$ & $10.77 \pm 1.3^{\mathrm{b}}$ & $21.73 \pm 2.62^{\mathrm{a}}$ & $* *$ \\
\hline
\end{tabular}

Means in the same row are bearing different letters, differ significantly $(\mathrm{P}<0.05)$. 
$* *=\mathrm{P}<0.01$,

$*=\mathrm{P}<0.05$,

N.S $=$ Not significant.

\section{Reproductive performance:}

\subsection{Doe and offspring traits}

Conception rate was significantly increased in doe Bouscat rabbits treated with either oxytetracycline or enrofloxacin as compared to that of the control (Table 6). Similar results were obtained by Abd El-Samee (1995) who found about $18 \%$ increase in conception rate in doe NZW rabbits treated with avoparcin compared to the control group. El-Tantawy et al. (2001 b) showed an improvement in conception rate in doe Bouscat rabbit treated with 100 or $200 \mathrm{mg} / \mathrm{kg}$ flavomycin.

Gestation length was insignificantly affected by either oxytetracycline or enrofloxacin treatment. Similar results were obtained by Rashwan (1993) and Afify and Makled (1994)..

Litter size at birth was slightly increased after treatment of doe Bouscat rabbits with either oxytetracycline or enrofloxacin, however, the litter size at 21 and 28 days of age was significantly increased with oxytetracycline and insignificantly by enrofloxacin both treatments. These results agree with those obtained by El-Gaafary et al. (1992) and Hanna (2000).

Litter weight at birth in treated rabbits with oxytetracycline was significantly improved followed by enrofloxacin as compared with control group. However, the increase in litter weight of the treated groups was not significant. These results are in agreement with those obtained by Hanna (2000) and Abo- Warda (2001)

The improvement in litter weight may be attributed to the fact that both oxytetracycline and enrofloxacin promote the bacteria in the digestive tract responsible for breakdown of cellulose and thus affords better utilization of feed oxytetracycline or enrofloxacin. They may also promote the growth of amyloytic and cellulytic microorganisms, which ferment both starch and cellulose (Giesccke and Hendrickx 1973).

At birth, the bunny weight was insignificantly improved in doe rabbits treated with either oxytetracycline or enrofloxacin as compared with the control group. The bunny weight at 21 and 28 days in the group treated with oxytetracycline was insignificantly decreased than that of the control group. The improvement was insignificant for litter weight gain from birth to 21 and to 28 days as compared to the control group. El-Tantawy et al. (2001b) reported a significant increase $(P<0.05)$ in litter weight gain from birth to 21 days and from birth to weaning in doe Bouscat rabbits treated with flavomycin.

The present data showed that both oxytetracycline and enrofloxacin injections significantly increased $(P<0.01$ or $P<0.05)$ the viability percentage of young Bouscat rabbits during the period from birth to 28 days of lactation.

\subsection{Milk yield:}

The results of Table 7 show that oxytetracycline and enrofloxacin injections significantly increased $(P<0.01$ or $P<0.05)$ the daily milk yield at $1^{\text {st }}, 2^{\text {nd }}$ and $3^{\text {rd }}$ week of lactation period of doe Bouscat rabbits as compared to that of the control group. However, daily milk yield at $4^{\text {th }}$ week of lactation period was insignificantly increased with either oxytetracycline or enrofloxacin injection. The improvement in daily milk yield may be attributed to the increased doe weight. Similarly, El-Tantawy 
et al. (2001 b) found that the daily milk yield of doe Bouscat rabbits treated with flavomycin was significantly increased $(P<0.05)$ from birth to weaning.

Table 6. Effect of oxytetracycline and enrofloxacin treatment on fertility traits of female Bouscat rabbits during the experimental period.

\begin{tabular}{|c|c|c|c|c|}
\hline \multirow{3}{*}{ Items } & \multicolumn{3}{|c|}{ Treatments } & \multirow{3}{*}{ Sig } \\
\hline & Control & Oxytetracycline & Enrofloxacin & \\
\hline & $\mathrm{X} \pm \mathrm{SE}$ & $\mathrm{X} \pm \mathrm{SE}$ & $\mathrm{X} \pm \mathrm{SE}$ & \\
\hline Number of mating & $1.76 \pm 0.16$ & $1.64 \pm 0.18$ & $1.45 \pm 0.12$ & NS \\
\hline Conception rate & $0.43 \pm 0.02^{\mathrm{c}}$ & $0.56 \pm 0.014^{\mathrm{b}}$ & $0.60 \pm 0.014^{\mathrm{a}}$ & $* *$ \\
\hline Gestation length (day) & $31.19 \pm 0.17$ & $31.4 \pm 0.36$ & $31.4 \pm 0.18$ & NS \\
\hline \multicolumn{5}{|l|}{ Litter size at: } \\
\hline Birth & $7.28 \pm 0.53$ & $7.79 \pm 0.58$ & $7.70 \pm 0.58$ & NS \\
\hline 21 days & $5.83 \pm 0.55^{\mathrm{b}}$ & $7.07 \pm 0.45^{\mathrm{a}}$ & $6.65 \pm 0.49^{b}$ & $*$ \\
\hline 28 days & $5.75 \pm 0.57^{b}$ & $7.07 \pm 0.45^{\mathrm{a}}$ & $6.65 \pm 0.49^{b}$ & $*$ \\
\hline \multicolumn{5}{|l|}{ Litter weight (g) } \\
\hline Birth & $328.89 \pm 21.86^{b}$ & $377.00 \pm 27.39^{a}$ & $356.00 \pm 29.86^{b}$ & $*$ \\
\hline 21 days & $1553.33 \pm 84.44$ & $1758.57 \pm 66.85$ & $1684.00 \pm 92.49$ & NS \\
\hline 28 days & $2506.25 \pm 140.42$ & $2652.14 \pm 150.7$ & $2635.0 \pm 159.13$ & NS \\
\hline \multicolumn{5}{|l|}{ Bunny weight at: } \\
\hline Birth & $45.18 \pm 2.79$ & $48.40 \pm 3.1$ & $46.23 \pm 2.35$ & NS \\
\hline 21 days & $266.44 \pm 17.47$ & $248.74 \pm 15.05$ & $253.23 \pm 16.3$ & NS \\
\hline 28 days & $435.87 \pm 32.65$ & $375.13 \pm 16.95$ & $396.24 \pm 20.83$ & NS \\
\hline \multicolumn{5}{|l|}{ Litter weight gain at: } \\
\hline Birth - 21 days & $1224.44 \pm 81.28$ & $1381.57 \pm 64.77$ & $1328.00 \pm 75.7$ & NS \\
\hline Birth- 28 days & $2177.36 \pm 134.1$ & $2275.00 \pm 140.12$ & $2279.00 \pm 42.28$ & NS \\
\hline $21-28$ days & $952.92 \pm 76.7$ & $893.57 \pm 109.66$ & $951.00 \pm 76.48$ & NS \\
\hline \multicolumn{5}{|l|}{ Viability (\%) at: } \\
\hline At birth & 96.30 & 98.20 & 97.47 & NS \\
\hline 21 days & $51.85^{b}$ & $89.19^{\mathrm{a}}$ & $83.54^{\mathrm{b}}$ & $* *$ \\
\hline 28 days & $51.11^{\mathrm{b}}$ & $89.19^{\mathrm{a}}$ & $83.54^{\mathrm{b}}$ & $* *$ \\
\hline $21-28$ day & 98.57 & 100 & 100 & NS \\
\hline
\end{tabular}

Means in the same row are bearing different letters, differ significantly $(\mathrm{P}<0.05)$.

$* *=\mathrm{P}<0.01, \quad *=\mathrm{P}<0.05, \quad$ N.S $=$ Not significant.

The present results showed that the milk yield value increased gradually up to $3^{\text {rd }}$ week and then decreased in $4^{\text {th }}$ week of lactation period in doe Bouscat rabbits. These results agree with El-Kelawy (1993) in New Zealand White rabbits.

Table 7. Effect of oxytetracycline and enrofloxacin treatment on daily of milk yield (g) of female Bouscat rabbits during the lactation periods.

\begin{tabular}{ccccc}
\hline \multirow{2}{*}{ Items } & \multicolumn{3}{c}{ Treatments } & \multirow{2}{*}{ Sig. } \\
\cline { 2 - 4 } & $\mathbf{C o n t r o l}$ & Oxytetracycline & Enrofloxacin & $\mathbf{X} \pm \mathbf{S E}$ \\
\cline { 2 - 4 } & $\mathbf{X} \pm \mathbf{S E}$ & $\mathbf{X} \pm \mathbf{S E}$ & & \\
\hline Milk yield at: & & & & \\
$1^{\text {st }}$ week & $95.50 \pm 4.56^{\mathrm{b}}$ & $114.64 \pm 5.61^{\mathrm{a}}$ & $123.25 \pm 6.24^{\mathrm{a}}$ & $*$ \\
$2^{\text {nd }}$ week & $138.75 \pm 8.94^{\mathrm{b}}$ & $153.57 \pm 9.98^{\mathrm{ab}}$ & $171.25 \pm 9.33^{\mathrm{a}}$ & $*$ \\
$3^{\text {rd }}$ week & $160.67 \pm 10.76^{\mathrm{b}}$ & $198.93 \pm 10.30^{\mathrm{a}}$ & $208.0 \pm 8.63^{\mathrm{a}}$ & $* *$ \\
$4^{\text {th }}$ week & $63.5 \pm 4.31$ & $96.43 \pm 9.29$ & $73.0 \pm 4.76$ & NS \\
\hline
\end{tabular}

Means in the same row are bearing different letters, differ significantly $(\mathrm{P}<0.05)$.

$* *=\mathrm{P}<0.01, *=\mathrm{P}<0.05, \mathrm{~N} . \mathrm{S}=$ Not significant. 


\section{Effect of oxytetracycline and enrofloxacin treatment on growing rabbits (Growth performance).}

Results of Table 8 showed that both oxytetracycline and enrofloxacin injection significantly increased $(P<0.01$ and $P<0.05)$ the daily weight gain from 5-9, 9-13 and 5-13 weeks of age of Bouscat rabbits. Moreover, antibiotic have beneficial effects in modification of gut bacterial population (Cheeke, 1987) and increase absorption and sparing of nutrients (Ghazalah et al., 1990).

Table 8. Effect of oxytetracycline and enrofloxacin treatment on daily weight gain (g), feed intake and economical performance of growing Bouscat rabbits during different age intervals.

\begin{tabular}{|c|c|c|c|c|}
\hline \multirow{3}{*}{ Items } & \multicolumn{3}{|c|}{ Treatments } & \multirow{3}{*}{ Sig. } \\
\hline & Control & Oxytetracycline & Enrofloxacin & \\
\hline & $\mathrm{X} \pm \mathrm{SE}$ & $\mathbf{X} \pm \mathbf{S E}$ & $\mathrm{X} \pm \mathrm{SE}$ & \\
\hline \multicolumn{5}{|l|}{ Weight gain from: } \\
\hline $5-9$ week & $21.69 \pm 0.24^{\mathrm{b}}$ & $23.92 \pm 0.58^{\mathrm{a}}$ & $23.48 \pm 0.58^{\mathrm{a}}$ & * \\
\hline $9-13$ week & $25.79 \pm 0.38^{\mathrm{c}}$ & $29.45 \pm 0.24^{\mathrm{a}}$ & $28.02 \pm 0.26^{\mathrm{b}}$ & $* *$ \\
\hline $5-13$ week & $23.74 \pm 0.28^{\mathrm{c}}$ & $26.68 \pm 0.34^{\mathrm{a}}$ & $25.75 \pm 0.26^{\mathrm{b}}$ & $* *$ \\
\hline \multicolumn{5}{|l|}{ Feed intake: } \\
\hline $5-9$ week & $67.57 \pm 0.92$ & $71.64 \pm 1.74$ & $69.99 \pm 0.61$ & NS \\
\hline $9-13$ week & $101.39 \pm 0.47$ & $98.07 \pm 1.06$ & $98.04 \pm 1.3$ & NS \\
\hline 5- 13 week & $84.48 \pm 0.31$ & $84.85 \pm 1.27$ & $83.5 \pm 0.44$ & NS \\
\hline \multicolumn{5}{|l|}{ Feed conversion from: } \\
\hline $5-9$ week & $3.12 \pm 0.06$ & $3.0 \pm 0.11$ & $2.99 \pm 0.07$ & NS \\
\hline $9-13$ week & $3.39 \pm 0.05^{\mathrm{a}}$ & $3.33 \pm 0.05^{\mathrm{a}}$ & $3.02 \pm 0.05^{\mathrm{b}}$ & $* *$ \\
\hline $5-13$ week & $3.56 \pm 0.04^{\mathrm{a}}$ & $3.18 \pm 0.07^{b}$ & $3.26 \pm 0.04^{\mathrm{a}}$ & $* *$ \\
\hline \multicolumn{5}{|l|}{ Economical performance: } \\
\hline Live weight (g) & 1641 & 2128.8 & 1923 & \\
\hline Total feed intake (g) & 5068.8 & 5091 & 5010 & \\
\hline Total weight gain (g) & 1424.4 & 1600.8 & 1545 & \\
\hline Price/ kg diet (pt.) & 85 & 94 & 91 & \\
\hline Price/ kg live weight ( $L$ E) & 11 & 11 & 11 & \\
\hline Feed cost ( L E) & 4.31 & 4.78 & 4.56 & \\
\hline Price of weight gain $(L E)$ & 15.67 & 17.61 & 16.9 & \\
\hline Net return & 11.36 & 12.83 & 12.34 & \\
\hline Economic efficiency & 263.6 & 268.41 & 270.61 & NS \\
\hline$\%$ Economic efficiency & 100.0 & 101.8 & 102.7 & NS \\
\hline
\end{tabular}

Means in the same row are bearing different letters, differ significantly $(\mathrm{P}<0.05)$.

$* *=\mathrm{P}<0.01, *=\mathrm{P}<0.05$, N.S $=$ Not significant.

The oxytetracycline and enrofloxacin treatments insignificantly affected the daily feed intake from 5-9, 9-13 and 5-13 weeks of age of female Bouscat rabbits. Baraghit (1991) reported that feed consumption tended to decrease with addition of antibiotic to diet in growing rabbits. El-Sayaad, (1997) observed a significant decrease in feed intake of treated male NZW rabbits with flavomycin as compared to the control group. El-Adawy et al. (2000) recorded a significantly lower feed intake $(P<0.01)$ in growing NZW rabbits treated with antibiotics. 
The present data showed that the daily feed conversion was insignificantly decreased during the period from 5-9 weeks of age of female Bouscat rabbits after either oxytetracycline or enrofloxacin treatment. However, it was significantly increased $(P<0.01)$ during the period from 9-13 and 5-13 weeks of age.

The improvement in feed efficiency may be due to an increase in the efficiency of nutrients absorption and nutrients utilization (Fairley et al., 1985). Also, the growth promoting effect induced by supplementation of antibiotics could be attributed to their antibacterial effect against Gram-positive organisms, which interferes with absorption of nutrients (Eyssen and De Somer, 1963) and due to its sparing effect of the metabolizable energy from the diet (March et al., 1978).

The present data showed that the economic efficiency and relative economic efficiency $\%$ of growing Bouscat rabbits treated with either oxytetracycline or enrofloxacin were slightly improved in comparing with the corresponding values of the control group.

Abd El-Samee (1995) found that treatment of growing New Zealand White rabbits with avoparcin $(200 \mathrm{ppm})$ or flavomycin $(125 \mathrm{ppm})$ improved the economical efficiency compared to the control. Radwan et al. (1996) found that higher value of economical efficiency of growing NZW rabbits recorded by treatment with lacto-sacc followed by treatment with virginiamycin compared to the control value. El-Tantawy et al. (2001 a) found that the growing Bouscat rabbits treated with flavomycin, kenzyme or lacto-sacc recorded the best economical efficiency value for treated rabbits with flavomycin followed by those feed k-enzyme.

\section{REFERENCES}

Abd El-Samee, A.M. (1995).Using some antibiotics and probiotics for alleviating heat stress on growing and doe rabbits in Egypt. World. Rabbit Sci., 3 (3): 107111.

Abo Warda, M.A. (2001). Effects of some growth promoters on productive and reproductive performance of rabbits. Ph. D. Thesis, Faculty of Agriculture, Kafr El-Sheikh, Tanta Univ., Egypt.

Afify, O.S. and Makled, M.N. (1994). Effect of prebiotic supplement on productive and reproductive performance of Bouscat rabbits. The Second Scientific Conference on Poultry, Kafr El-sheikh, Egypt, pp: 93-106.

Anadon, A.; Martinez-lannanage, M.R.; Diaz, M.J.; Velez, C. and Bringas, P. (1990). Pharmacokinetic and residue studies of quinolone compounds and alaquindox in poultry. Ann. Res. Vet., 21 (7). 137-144.

Baraghit, G.A. (1991). Effect of avoparcin level as a growth-promoting agent for rabbits. Minufiya J. Agric. Res., 16: 301-313.

Blight, L. and White, G. (1983). ${ }^{125}$ I-Labeled radioimmunoassay Kits for progesterone evaluated for use in an in vitro fertilization program. Clin. Chem., 29: 1024-1027.

Brown, S.A. (1996). Flouroquinolones in animal health. J. Vet. Pharmacol. Thera., 19: $1-14$.

Bryand-Green, W.G.D.; Green-Wood, F.C.; Marados-Simmen, R.; Weiss, T.; Xamanota, S.; Veno, M. and Arakaki, R. (1982). Relaxine secretion and relaxine receptor. Ann. NY. Acad. Sci.; 380: 100-110. 
Burgmann, P. (2000). Antimicrobial drug use in rodents, rabbits and ferrets, In: Prescott, J.F.; Baggots, J.D. and Walker R.D. (3rd ed.). Antimicrobial Therapy in Veterinary Medicine, Iowa State University Press. Ames, USA, pp: 656-677.

Chapman, H.D. and Johnson, Z.B. (2002). Use of antibiotics and roxarsone in broiler chicken in USA: analysis for the years 1995 to 2000. Poultry Sci., 81: 356-364.

Cheeke, P.R. (1987). Rabbit Feeding and Nutrition. Academic press Inc., London.

Cheeke, P.R.; Patteon, N.N. and Templetom, G.S. (1982). Rabbit production. Institute Printers and Publishers, Inc., Danville, Illiois, USA, Fifth edition.

Clark, J.D.; Jain, A.V. and Hatch, R.C. (1982). Effects of various treatments on induced chronic aflatoxicosis in rabbits. Am. J. Vet. Res., 43 (1). 106-110.

Cuilleron, C.Y. and Forest, M. (1990). Comparison of merits of steroid radioimmunoassays using iodinated or tritiated radioligands. Nucl. Med. Biol., 17 (7): 661.

Dorgham, S.M.; Sabri, H.M. and El-Sheikh, M.A. (1994). Influence of fermacto, virginiamycin egg-plus as growth promoters and their synergetic effects on laying hen performance. Proceeding of 2nd Scientific Conference on Poultry, Kafr El-Sheikh, Egypt.

Duncan, D.B. (1955). Multiple range and multiple F tests. Biometrics, 11: 1-42.

El-Adawy, M.M.; Borhami, B.E. and Bassuny, S.M. (2000). Effects of lact-A-Bac vs Stafac*20 on the performance of growing New Zealand White rabbits. Egypt. J. Rabbit Sci., 10 (1). 43 -59.

El-Banna, H.A. and Ibrahim Sh.A. (1999). Diclazuril interaction with avoparcin and virginiamycin as growth promoters in growing rabbits. Vet. Med. J. Giza, 47 (4). 445-455.

El-Gaafary, M.N.; Rashwan A.A.; El-Kerdawy D.M.A. and Yamani, K.A. (1992). Effects of feeding pelleted diet supplemented with probiotic (lacto-sacc) on digestibility growth performance blood constituents, semen characteristics and reproductive traits of rabbits. Egypt. J. Rabbit Sci., 2 (2): 95-106.

El-Kassas, N.E. (2005). Seasonal effects of some veterinary antimicrobial agents on the fertility parameters of male rabbits. M. Sc. Thesis, Faculty of Science, Tanta Univ., Egypt.

El-Kelawy, H.M. (1993). Studies on reproductive and productive performance in rabbits. Ph. D. Thesis, Faculty of Agriculture, Zagazig Univ., Egypt.

El-Sayaad, G.A.E. (1997). Flavomycin as growth promoter for rabbit diets. Egypt. J. Rabbit Sci., 7 (1): 47-56.

El-Sherbiny, A.E.; El-Samra, S.H.; Raafat, M.A. and El-Nagmy, K.Y. (1990). Antibiotics as growth promoters in broiler ration. 2- Effect of flavomycin or zinc bacitracin supplements on dressing giblet, intestinal weights and plasma protein contents. J. Agric. Sci., Mansoura Univ., 15: 399-405.

El-Tantawy, S.M.T.; Meshreky, S.Z.; Nosseir, F.M. and Hanna, M.F.S. (2001a). Effects of some feed additives on: 1- Productive performance, carcass traits and some blood constituents of growing Bouscat rabbits. Egypt. J. Nutr. Feeds, 4 (Special issue). 931-943.

El-Tantawy, S.M.T.; Meshreky, S.Z.; Nosseir, F.M. and Hanna M.F.S. (2001 b). Effect of some feed additives on: 2- Reproductive performance and some blood 
hormones of Bouscat rabbits does. J. Anim. Nutr. Feeds, 4 (Special issue). 945956.

Enbergs, H. (1979). Radio immunological investigations on the level of progesterone in the peripheral blood of pregnant rabbit with reference to season and number of young. Berliner and Miinchener Tierarzttiche Wocherschrift., 92: 32-34.

Everitt, B.S. (1977). The analysis of contingency Tables. Monographs of Applied Probability and Statistics. London Chapman Hall, pp: 38-66.

Eyssen, H. and De Somer, P. (1963). The mode of action of antibiotics in stimulating growth of chicks. J. Exp. Med., 117: 127-138.

Fairley, C.; Chanter, D.O.; Meallister, A.; Roberts, N.L. and Smith, H. (1985). Effect of avoparcin interaction of broilers. British Poultry Science, 26: 465-471.

Fleischer, L.G.; Gerber, G.; Liezenga, R.W.; Lippert, E.; Scholl, M.A. and Westpha, L.G. (2000). Blood cells and plasma proteins of chickens fed a diet supplemented with beta-D-glucan and enrofloxacin. Arch. Tierernahr., 53 (1):59-73.

Ghazalah, A.A.; Baulos, N.Z.; El-Abbady, M.R. and Ali, A.M. (1990). Using some antibiotics as growth promoters and their sparing effect on protein in broiler rations. $3^{\text {rd }}$ Conf. Agric. Dev; Res. Faculty of Agric., Ain Shams University, Cairo, Egypt, Annals Agric. Sci., Special issue: 627-649.

Giesccke, D. and Hendrickx, K.H. (1973). Biologie and Biochemie der mikrobiellen verdang $B L V$. Verlagsgesellschaft, Munchen Bern, Wein.

Habeeb, A.A. and El-Masry, K.A. (1991). Hormonal pattern in pregnant rabbits and some productive aspects as affected by litter size at birth. Egypt. Poultry Sci., 11: 429 .

Hanna, M.F.S. (2000). Effects of some growth promoters on reproductive performance and carcass traits in rabbits. Ph. D. Thesis, Faculty of Agriculture, Cairo Univ., Egypt.

Hawk, P.B. (1965). Physiological Chemistry. $14^{\text {th }}$ ed., McGraw Hill Book Company, London, pp: 1124-26.

Henry, R.J. (1964). Clinical Chemistry. Harper and Row Publishers, New York pp: 181.

Henry, R.J. (1974). Clinical Chemistry, Principles and Techniques., $2^{\text {nd }}$ edition, Harper and Row, pp: 525.

Kamar, G.A.R.; Shafie, M.M. and Abd El-Malak, E.G. (1975). Temperature gradient rabbits in relation to heat tolerance. Egypt. J. Anim. Prod., 15: 47-56.

Lebas, F. (1983). Small-scale rabbit production. Feeding and management systems. World Anim. Rev., a: 11-17.

March, B.E; Soong, R. and Mac Millan, C. (1978). Growth rate, feed conversion and dietary metabolizable energy in response to virginiamycin supplementation of different diets. Poultry Sci., 57: 1346-1350.

Mignot, A.; Lefebre, M.A. and Milleriux, L. (1993). Determination of spiramycin and neomycin in biological samples (Plasma, muscle, liver, kidney, skin and fat) from a residue study in chicken CEPHAC Report, No. CD 508.

Miles, R.D.M.; Janky, D. and Harms, R.H. (1984). Virginiamycin and broiler. Poultry Sci., 63: 1218-1221.

Navalon, A.; Blanc, R.; Reyes, L.; Navas, N. and Vilchez, J.L. (2002). Determination of the antibacterial enrofloxacin by differential-pulse adsorptive stripping voltametry. Analytica. Chimica. Acta., 454 (1): 83-91. 
N.R.C. (1977). Nutrient Requirements of Rabbits. $2^{\text {nd }}$ Review. Edition. National Academy Science, USA.

Prescott, J.F.; Baggot, J.D.; Walker, R.D. (eds.) (2000). Antimicrobial Therapy in Veterinary Medicine. Iowa State University Press, Ames, USA, pp: 275-289.

Radwan, M.S.M.; Asker, N.; El-Nagaar, N. and Abd El-Lateef, A. (1996). LactoSacc and virginiamycin supplementation for growing rabbits under subtropical condition. Egypt. J. Rabbit Sci., 6: 99-108.

Rashwan, A.A. (1993). Reproduction performance of New Zealand White rabbits as affected by dietary supplementation with Lacto-sacc, Bospro and a mixture of them under Egyptian environmental conditions. Egypt. J. Rabbit Sci., 3 (2). 163169.

Reitman, S. and Frankel, S. (1957). Determination of serum glutamic oxaloacetic and serum pyruvic transaminases. Am. J. Clin. Path., 28: 56-60.

Sharma, S.C. (1979). Temporal changes in PGE, PGE-O, oestradiol-17 and progesterone in uterine venous plasma and endometrium of rabbits during early pregnancy. Proceedings of the International Symposium on Prostaglandin, J. Endocrinol., 44: 437-450.

Snedecor, G.W. and Cochran, W.G. (1982). Statistical Methods. $7^{\text {th }}$ Edition. Iowa State. University, Press, USA.

SPSS (1997). SPSS user's Guide statistics version 8 copyright SPSS Inc., USA.

Van den Bulck, K.; Decostere, A.; Gruntar, I.; Baele, M.; Krt, B.; Ducatelle, R. and Haese, B.F. (2005). In vitro antimicrobial susceptibility testing of Helicobacer felis, H. bizzozeronii, and H. salomonis. Antimicrob. Agents Chemother., 49 (7). 2997-3000.

Verma, H.k.; Pangawkar, G.R.; Matharoo, J.S. and Spivastava, A.K. (1999). Effect of enrofloxacin on the seminal attributes of Buffallo Bulls. Indian Vet. J., 76: 1020-1022.

Villa, R.; Cagnardi, P.; Bacchetta, S.; Sonzogni, O.; Faustini, M. and Carli, S. (2001). Tissue distribution and residue depletion of oxytetracycline in the rabbit. World Rabbit Sci., 9 (4). 159-164.

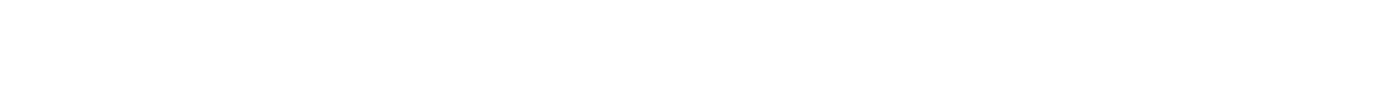

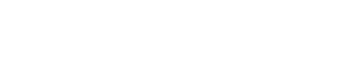

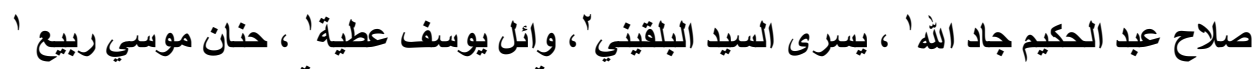

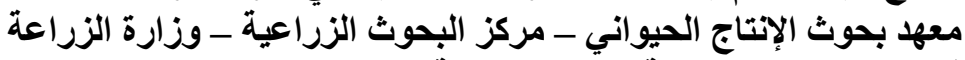

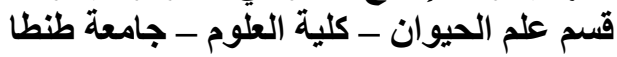

$$
\begin{aligned}
& \text { اشتملت هذه الدر اسة جزئين أساسيين. الجزء الأول استخدم فيه ب؟ أنثي أرنب بوسكات عمر } 7 \text { شهور }
\end{aligned}
$$

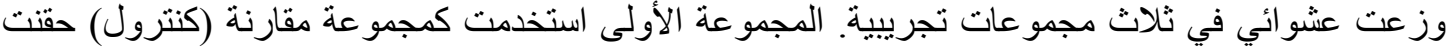

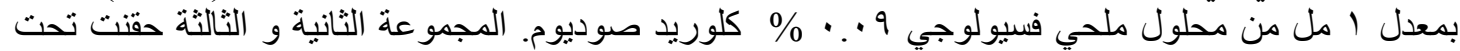

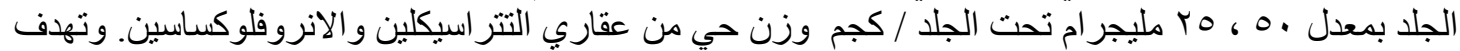

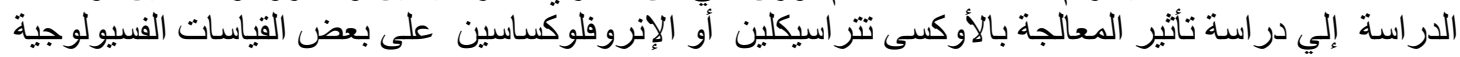

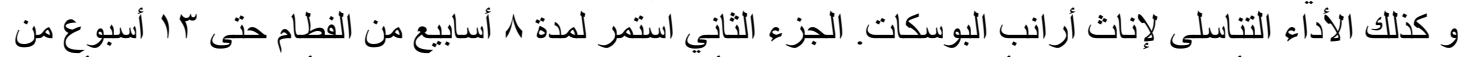

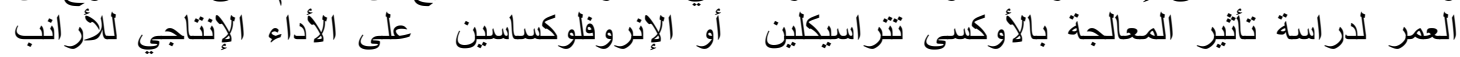

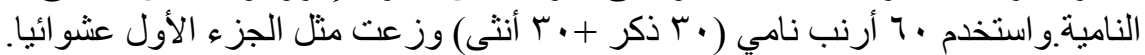




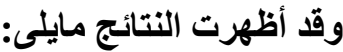

أظهرت الدر استة زيادة الوزن الكلى للجسم بالمعاملة بكلا العقارين مقارنة بالكنترول.

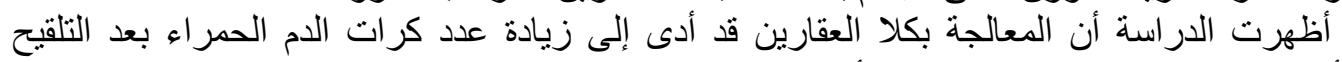

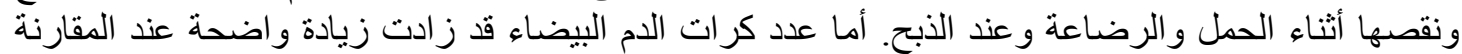

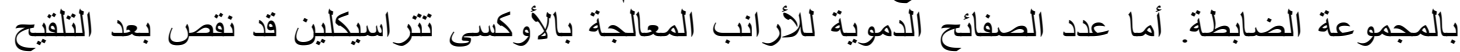

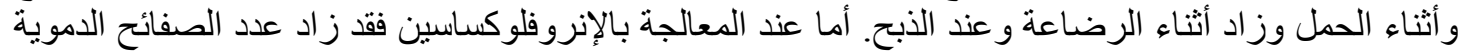

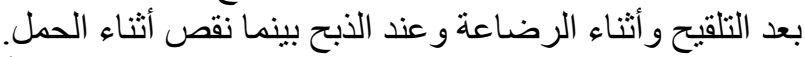

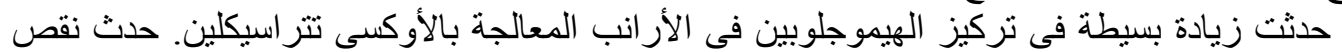

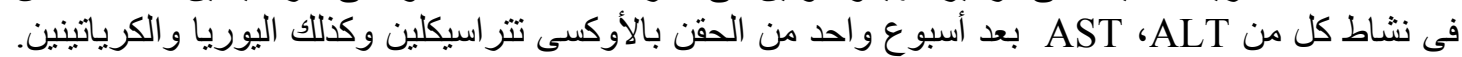

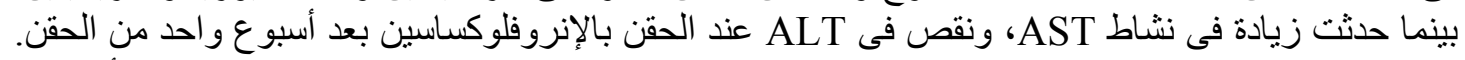

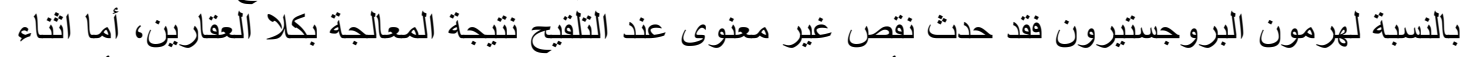

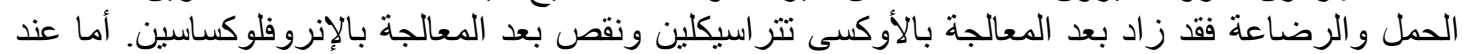

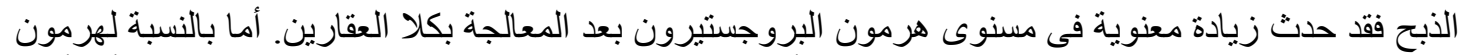

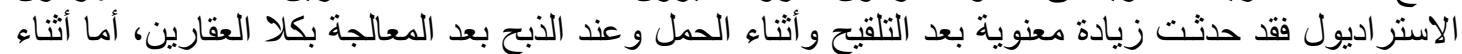

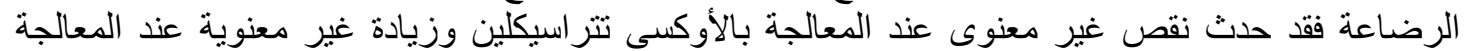

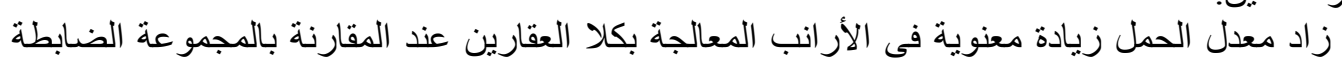
بالإنروفلوكساسين.

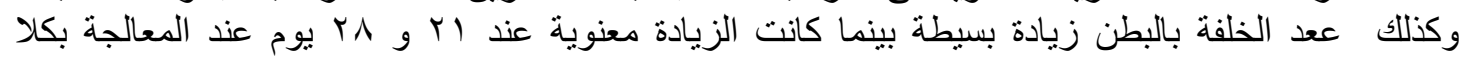

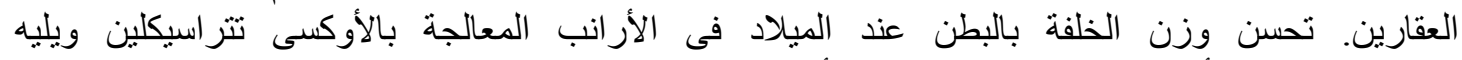

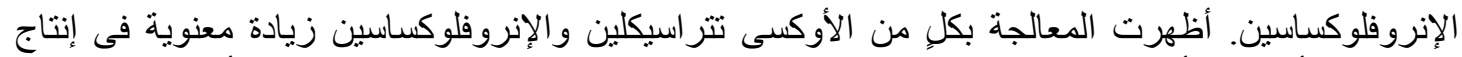

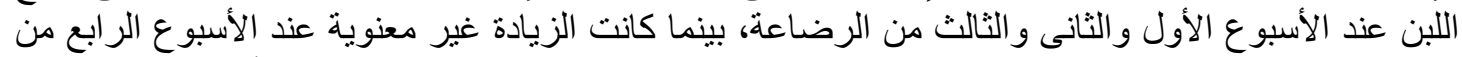

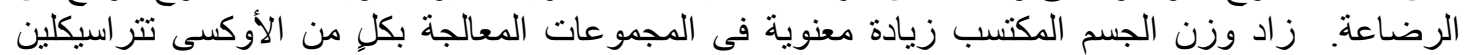

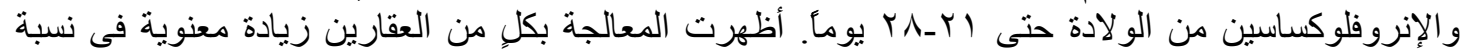

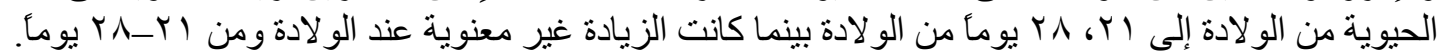

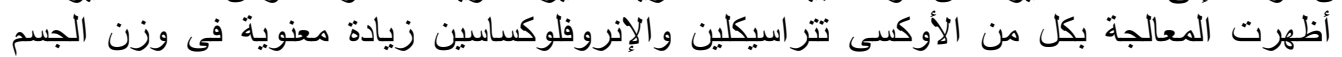

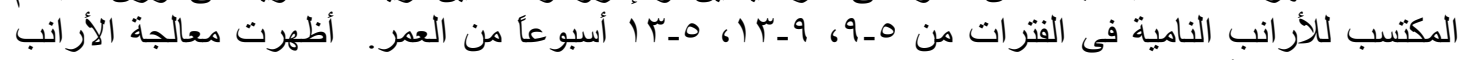

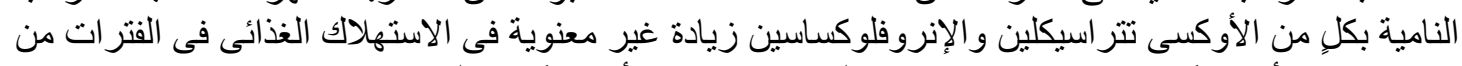

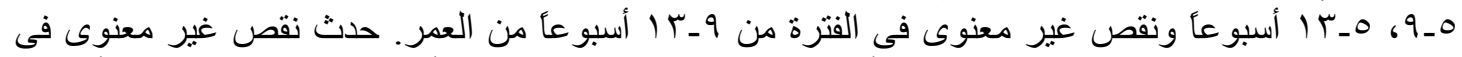

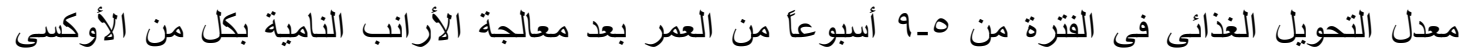

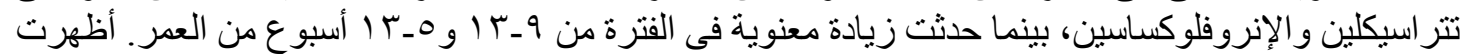

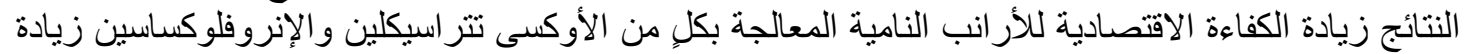

